\title{
Study on the Interaction between International Commodity Price and China's Demand
}

\author{
Xunkang Zhuo \\ Jinan University, Guangzhou, China \\ Email: zhuoyep@foxmail.com
}

How to cite this paper: Zhuo, X. K (2018). Study on the Interaction between International Commodity Price and China's Demand. Chinese Studies, 7, 34-46. https://doi.org/10.4236/chnstd.2018.71004

Received: January 15, 2018

Accepted: February 10, 2018

Published: February 13, 2018

Copyright $\odot 2018$ by author and Scientific Research Publishing Inc. This work is licensed under the Creative Commons Attribution International License (CC BY 4.0).

http://creativecommons.org/licenses/by/4.0/

\section{c) (i) Open Access}

\begin{abstract}
Based on monthly data and VAR models from March 2002 to December 2015, this paper studies the interaction between international commodity price and China's demand. The results show that the impact of China's demand can to a certain extent guide the fluctuation of commodity prices, while this impact is insignificant. Over time, the shock of commodity prices has exerted an increasingly effect on the changes in China's demand. In the context of the drastic drop of commodity prices and the slowdown of international economic growth, China should pay close attention to other factors that affect the volatility of commodity prices, such as speculative investment factors, the monetary policy of the world's major economies and take full advantage of today's low commodity prices and take muscular internationalization approach to buying important commodities cheaply for eventual global market improvement and selling on the macroeconomic trendlines.
\end{abstract}

\section{Keywords}

International Commodity Price, China’s Demand, VAR Model

\section{Introduction}

After the financial crisis, the international commodity price volatility has gone through roughly three phases (as shown in Figure 1): All the way up in 2009-2011, the slowing down in 2011-2014 and the slump in 2014-2015. The volatility of the international commodity price has brought many uncertainties to the economic development of all countries. Therefore, the fluctuations of international commodity price and its causes have become the hot topics of academia. This paper focuses on the Chinese factors in commodity prices: We use the $\mathrm{CRB}$ index and the growth rate of industrial output respectively as the indicators of commodity prices and Chinese demand, and based on the monthly data from 


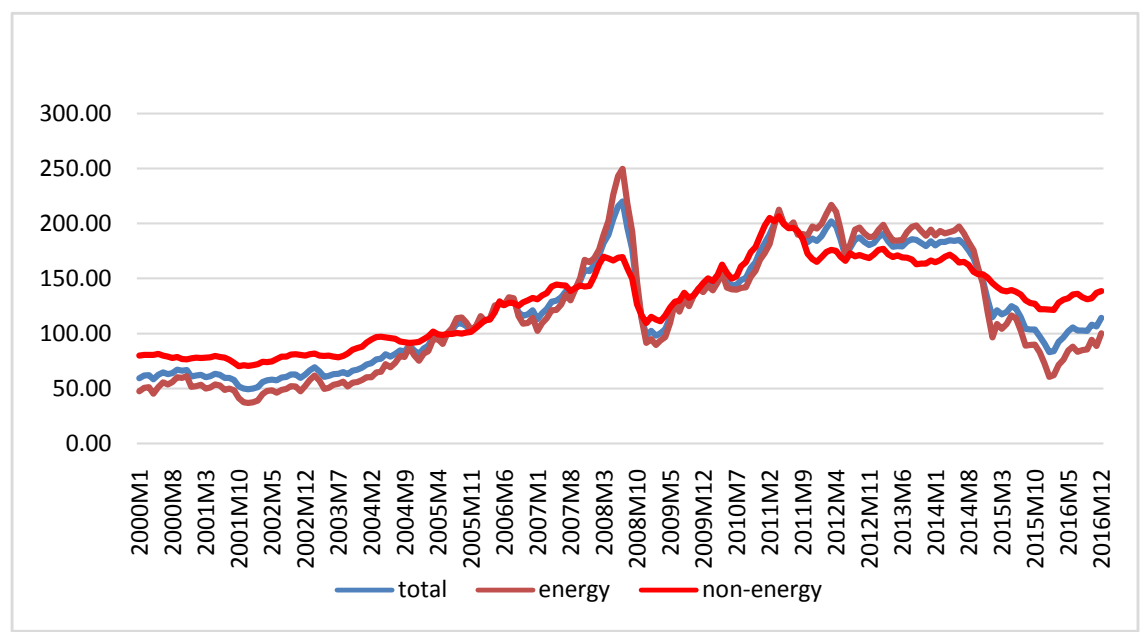

Figure 1. International commodity price Index. Source: IMF.

March 2002 to December 2015, we construct a VAR model to analyze the interaction between international commodity price and Chinese demand.

\section{Literature Review}

The literature on the drivers of commodity price volatility is divided into three categories: the aspect of supply and demand, investment and speculation, and monetary factors.

The aspect of supply and demand. Cheung \& Sylvie (2007) and Lalonde et al. (2009) analyze the relationship between emerging economies in Asia and commodity price volatility, pointing out that the economic performance of emerging economies in Asian has a greater impact on commodity prices; Hamilton (2009), Kilian (2009), Kilian and Murphy (2011), Sanders and Irwin (2010), Inamura et al (2011), Dwyer, Holloway, Wright (2012), Arbatli and Vasishtha (2012) hold that the fluctuations of commodity price reflect the changes in real supply and demand, and the rapid economic growth in emerging economies, especially in China, led to the continuously increase in demand for commodities including energy, metals and agricultural products, which directly led to the tremendous increase in the commodity prices in 2003-2012. Han and Yin (2012) analyze the factors that affect the commodity prices by using the FAVAR model, they find that in the long run, the development of economy is the main driving force of commodity prices. Roache and Rossi (2010) finds that the impact of China on the international commodity markets is strengthening, but this impact is less than The United States, and the Chinese factor does not have a significant impact on all commodities. Wang (2013) uses SVAR model to quantitatively analyze the changes of commodity prices, and finds that the financialization of international commodities and the rapid economic growth in China have played a crucial role in the change of commodity prices in the past 10 years. Among them the financial factors have a greater impact on commodity prices. Tan et al. (2014) construct the global indicators and use VECM model to study the drivers 
of international commodity price, pointing out that aggregate demand is the main factor affecting the international commodity price and the impact of China on international commodity price is increasing but not as significant as that of developed countries. Li \& Mu (2015) use the PVAR model to analyze the fluctuations of international commodity market prices and the influencing factors from a global perspective, they find that the development of real economy has a strong and persistent impact of commodity price and in the short term, the monetary factors have greater impact.

The aspect of investment and speculation. Gilbert (2010) uses the monthly data of CFTC investors' futures positions from 2006 to 2009 to construct the position index of agricultural products futures and finds that investors' positions have a significant impact on the prices of agricultural products and crude oil. Singleton (2011) finds that the positions of investors have a significant impact on the price of crude oil futures. Baldi et al. (2011) find that the growth of demand and financial speculation are the causes of fluctuations in commodity prices, among that the breadth and depth of futures markets plays an important role in the discovery of commodity prices. Based on the FAVAR model with sign constraint, Juvenal and Petrella (2011) find that speculative factors have strong explanatory power for fluctuations of oil price from 2004 to 2008. Han and Yi (2012) analysis the influencing factors of the commodity prices by the vector autoregressive (FAVAR) model and find that in the short run, the international speculative factors lead to the financialization of the commodity futures. Wang (2013) uses the SVAR method to quantitatively analyze the changes of commodity prices and points out that the financialization of commodities and the rapid development of economic in China have played a crucial role in the changes of commodity prices in the recent 10 years. Among them, the speculative factors have a greater impact on the prices of commodities. Manera, Nicolini and Vignati (2012) find that speculation does have a significant impact on the fluctuation of oil prices in the 21 st century. In particular, in short term the impact of speculation is pretty obvious.

The aspect of currency factor. Based on the SVAR model, Anzuinie et al. (2010) analyze the impact of the federal funds rate and the money supply on the commodity prices. It was found that the decrease of the interest rate boosted the rise of the commodity prices, while the increase of the money supply has less impact on the commodity prices. Landgraf \& Chowdhury (2011) finds that the monetary factors in the OECD countries have no significant effect on the prices of international commodities. However, the impact of the monetary factors on the international commodities prices has been significantly enhanced after the inclusion of the BRICS countries. Thompson and Summers (2012) found that the correlation coefficients between the 26 commodity prices and real interest rates show significant structural changes in the early 1980s: the coefficients turned from negative to positive and the factors such as demand, risk aversion and index investment are more convincing than the real interest rates in ex- 
plaining the changes of commodity prices. Belke et al. (2013) finds that there was a long-term positive correlation between commodity prices and global liquidity and a negative correlation with interest rates. Tan et al. (2014) finds that the global financial crisis affected the pricing mechanism of commodity markets; the impact of global liquidity on international commodity price was more pronounced before the crisis. Li \& $\mathrm{Mu}$ (2015) finds that the effect of the real economy on commodity price volatility is more persistent, and the short-term impact of monetary and financial factors is stronger. The interest rate policy of developed countries and the monetary policy of emerging market countries are the important reasons for the fluctuation of commodity prices.

The literature on the impact of commodity price volatility on the economy is as follows: Han (2006) conducts an empirical study on the relationship between exchange rate, crude oil price and China's economic growth based on the error correction model. The results show that there is a long-term co-integration relationship between the crude oil price and China's economic growths. Blanchard \& Jordi (2007) studies the effects of rising oil prices on inflation and economic growth based on four different assumptions and concludes that changes in crude oil prices over time diminish the impact on wages, output and employment. Blattman et al. (2007) analyzes data from 35 commodity-exporting countries between 1870 and 1939 and finds that fluctuations in the terms of trade resulting from the dramatic fluctuations in commodity prices would reduce foreign investment and thereby affect the economic growth in those countries. Balke et al. (2008) establishes a Bayesian autoregressive model to study the impact of changes in crude oil supply and demand on the economy and concludes that the impact of changes in supply and demand on crude oil prices and industrial output is obviously notable. By analyzing the trend of index, Chang (2010) points out that the commodity market information is generally ahead of the domestic economic indicators by half a year, indicating that the index can be forecast in advance according to the price of commodity futures, which will transmit inflation warning signal and play a directional role in the economic development. Based on the GARCH-BEKK model and the VAR model, Li et al. (2009) uses the method of wavelet transform to analyze the flat zone, and concludes that the one-way mean spillover effect of international oil prices on inflation in China is significant in a short period. Cavalcanti et al. (2012) uses the standard system GMM method and the average cross-section mixed group method to analyze the impact of the level and volatility of commodity trade conditions on economic growth between 1970 and 2007, and find that: the improvement of terms of trade has a positive impact on real GDP per capita, while its volatility will have a negative impact and therefore will greatly offset the positive impact of the previous one. He \& Chen (2014) tests the correlation between the international commodity price (RJ/CRB Index) and China's PPI Index and find that there is a significant correlation between international commodity price and China's PPI index, and that the CRB index leads the PPI index by about two months, which can be 
used as a leading indicator to forecast China's PPI index.

\section{Commodity Price Volatility and Chinese Factors}

Based on the above research, this paper focuses on the Chinese factors that cause the fluctuation of commodity prices in recent years, and study the interaction between the change of demand in China and the change of international commodity price.

In the past two years, especially in 2015 , with the commodity prices continued to decline, China's economic growth also showed a downward trend, which seems to support the assertion in recent years that the changes of China's demand are an important promoter of the fluctuations of international commodity price. According to statistics, the Bloomberg Commodity Price Index dropped by $24.7 \%$ in 2015 , of which the crude oil and gold markets were particularly impressive. Meanwhile, China's GDP grew by $6.9 \%$ in 2015 , which is the first time that dropped below $7 \%$. In fact, the fluctuation of international commodity prices has shown a strong endogenous correlation with the economic growth in our country over the past decade. With the rapid economic growth, the shift of global manufacturing to China has prompted China to gradually become the major supplier of bulk raw materials and the main supplier of global products. Take the non-ferrous metals in China as an example. Figure 2 presents the relationship between the international commodity price index and the growth of China's industrial output value from January 2002 to October 2015. Figure 3 shows the imports of non-ferrous metals in China, reflecting China's demand for commodity prices. There are roughly five periods as follows:

Period 1: the period of continuous rise from early 2002 to June 2008 . The rise in this period was mainly caused by the transformation of the third scientific and technological revolution in the United States into productive forces and the rapid development of the BRIC countries. During this period, China joined the WTO and achieved the rapid economic growth, which reflected in the rapidly upward trend of imports of non-ferrous metals in Figure 3.

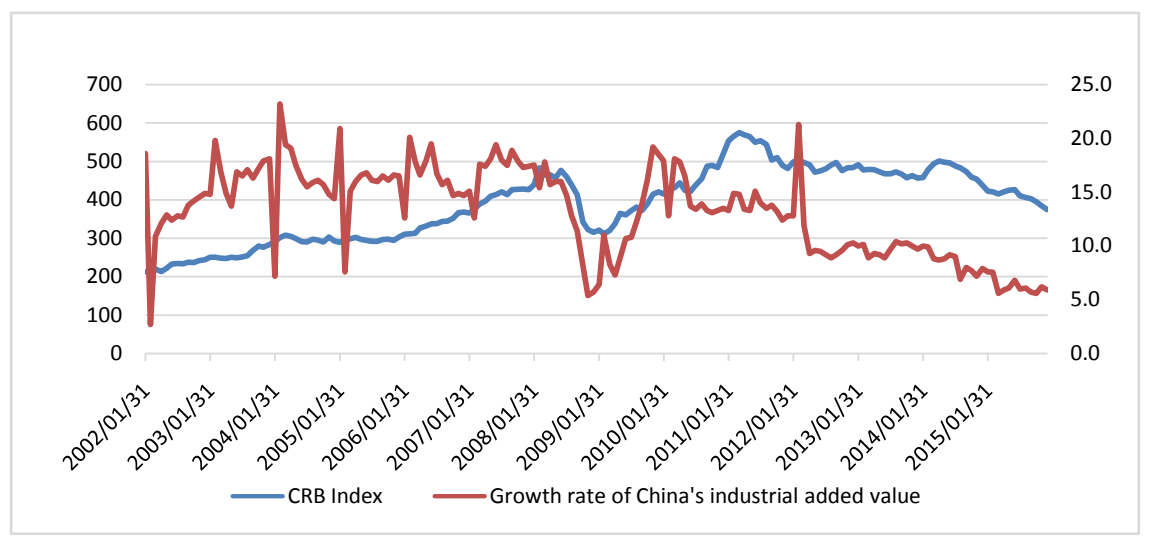

Figure 2. CRB Index and the growth rate of China's industrial added value. Source: IfinD Database. 


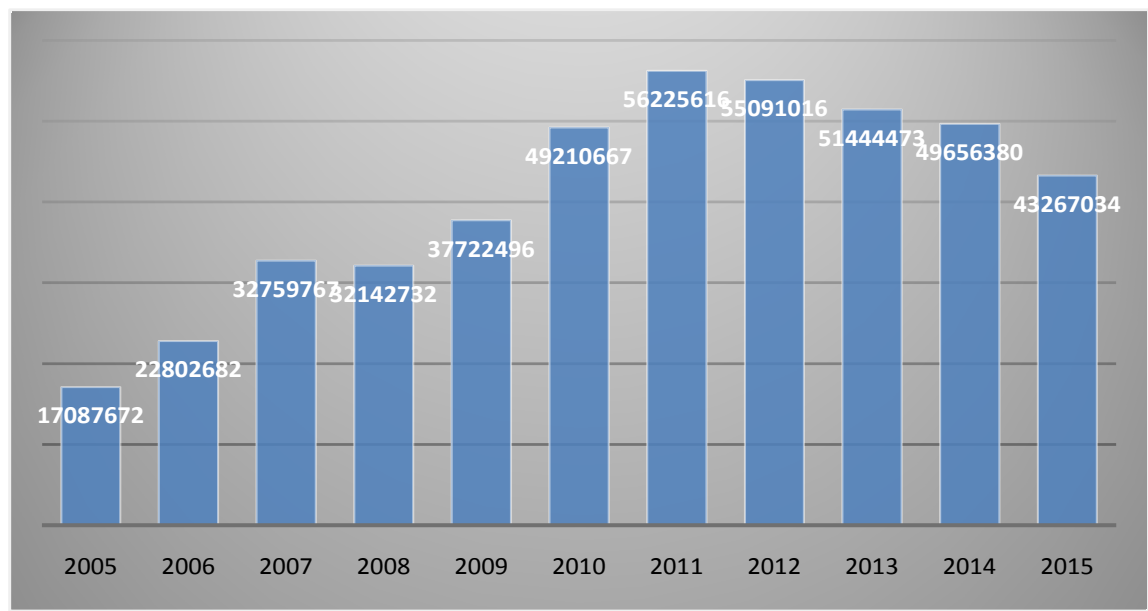

Figure 3. China's imports of non-ferrous metals. Source: http://www.haiguan.info/.

Period 2: the collapse period from July 2008 to December 2008. The reasons for the slump at this period were mainly the outbreak of the global financial crisis and the slowdown in the international economic growth. The demand for nonferrous metals in China began to decease this year.

Period 3: the rapid rise period from January 2009 to May 2011. After the outbreak of the financial crisis, the G20 countries jointly adopted stimulative policies and the international commodity price continued to rise. Meanwhile, the 4 trillion yuan investment stimulus plan released by China also pulled up the prices of international commodities to a certain extent. In Figure 3, It can be seen that the demand for non-ferrous metals in our country at this period has surged.

Period 4: stabilization period from June 2011 to September 2014. Prices dropped slightly after June 2011, and then returned to their original position. A sharp drop occurred in the first half of 2012, after which commodity prices began to enter a relatively steady period. During this period, China's economy entered into a stable growth period. In Figure 3, China's demand for non-ferrous metals declines year by year, but the decline rate is not big. Generally speaking, the demand is relatively stable.

Period 5: A sharp decline from September 2014 to December 2015. After September 2014, international commodity price declined rapidly. The main reason for this is the slowdown in global economic growth, which in turn reduces the demand for commodities. Meanwhile, during this period, China's economic growth slowed down and the import of non-ferrous metals dropped sharply.

Based on the above analysis, we find that there is a strong endogenous correlation between the international commodity price and China's economic growth. Especially after 2011, the changing trend of China's demand is in line with that of international commodity price.

\section{VAR Model Analysis}

\subsection{Data}

Combined with the above analysis, in order to further explore the relationship 
between the international commodity price and China's economic growth, based on the monthly data from March 2002 to December 2015, this paper uses the $\mathrm{CRB}$ index(CRB)to represent the international commodities price and the growth rate of China's industrial added value $(\mathrm{CN})$ to represent the changes in China's demand. For reducing the heteroskedasticity, these two sets of data are in the form of natural logarithms.

\subsection{Stationarity Test and Cointegration Test}

\subsubsection{Stationarity Test}

We use ADF Unit root test method to test the time series stability of international commodity price (LNCRB) and the growth rate of China's industrial added value (LNCN). As shown in Table 1, both LNCRB and LNCN can not reject the null hypothesis that there is a unit root, that is to say, they are non-stationary sequences; however, their first-order differential time series DLNCRB and DLNCN can reject the null hypothesis that there is a unit root at $1 \%$ significance level, so the first-order differential time series are stationary sequences.

\subsubsection{Cointegration Test}

From Table 1, we can see that LNCRB and LNCN are non-stationary sequences, but their first-order differential sequences are stationary sequences and thus satisfy the condition of cointegration test. Here we use the Engle-Grange two-step cointegration test. At first we use OLS to estimate the equation, the result is as follows:

$$
\mathrm{LNCRB}=6.63-0.25 \mathrm{LNCN}
$$

Secondly, we use the ADF unit root method to test the time series stability of the residual item of Equation (1). And then we find that the residual item can reject the null hypothesis of unit root at the $5 \%$ significance level, which indicates that the residual item of Equation (1) is a stationary sequence. Therefore, we can conclude that the LNCRB sequence and the LNCN sequence have successfully passed the cointegration test. In the presence of cointegration, we establish a VAR model for further study.

\subsection{VAR Model Estimation}

\subsubsection{VAR Model Stability Test}

As shown in Figure 4, the inverse roots of characteristic polynomial of the VAR

Table 1. The results of ADF unit root test.

\begin{tabular}{cccccccc}
\hline variables & $\begin{array}{c}\text { Type } \\
(\mathrm{t}, \mathrm{c}, \mathrm{n})\end{array}$ & $\begin{array}{c}\text { ADF } \\
\text { statistics }\end{array}$ & conclusions & variables & $\begin{array}{c}\text { Type } \\
(\mathrm{t}, \mathrm{c}, \mathrm{n})\end{array}$ & $\begin{array}{c}\text { ADF } \\
\text { statistics }\end{array}$ & conclusions \\
\hline LNCRB & $(\mathrm{t}, \mathrm{c}, 2)$ & -1.09 & Non-stationary & LNCN & $(\mathrm{t}, \mathrm{c}, 2)$ & -3.12 & Non-stationary \\
DLNCRB & $(0,0,1)$ & $-7.2^{*}$ & stationary & DLNCN & $(0,0,1)$ & $-12.36^{*}$ & stationary \\
\hline
\end{tabular}

Note: $\mathrm{D}$ represents the first-order difference, $\mathrm{t}$ in the test type represents the trend term, $\mathrm{c}$ represents the intercept term, $\mathrm{n}$ represents the lag order of the variables (as determined by the AIC information criterion), and ${ }^{*}$ indicates the significance level at $1 \%$. 
model fall within the unit circle, indicating that the VAR model is stable and it is available for impulse response and variance decomposition analysis to further investigate the dynamics relationship between the international commodity price and the growth rate of China's industrial added value.

\subsubsection{Impulse Response Analysis}

Impulse response function describes the impact of the shock from a variable on the current and future value of the endogenous variables. Figure 5 and Figure 6 are the impulse response functions of the impact of international commodity price on the growth rate of industrial added value and the impact of the growth rate of industrial added value on the prices of international commodity price.

As can be seen in Figure 5, the response of the international commodity price to one standard deviation shock from the growth rate of industrial added value is positive, then it reaches the maximum value 0.012 in the fifteenth period, and then the positive response fades out and disappears. The result shows that with the China's industrial output growth accelerated, the international commodity

Inverse Roots of AR Characteristic Polynomial

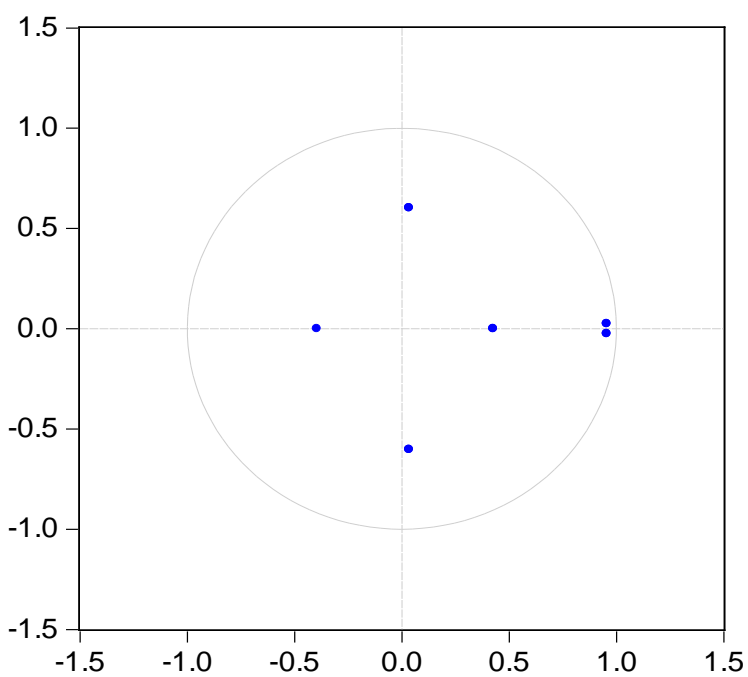

Figure 4. VAR model stability test.

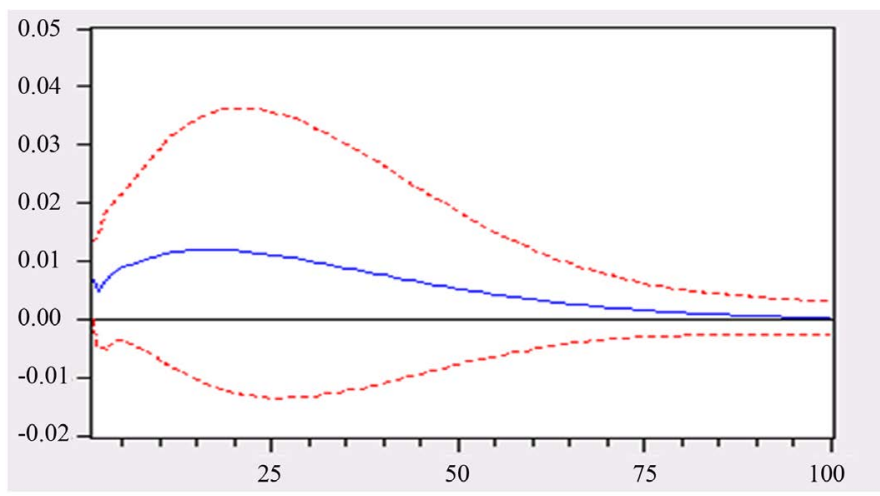

Figure 5. Impulse response of LNCRB to LNCN. 


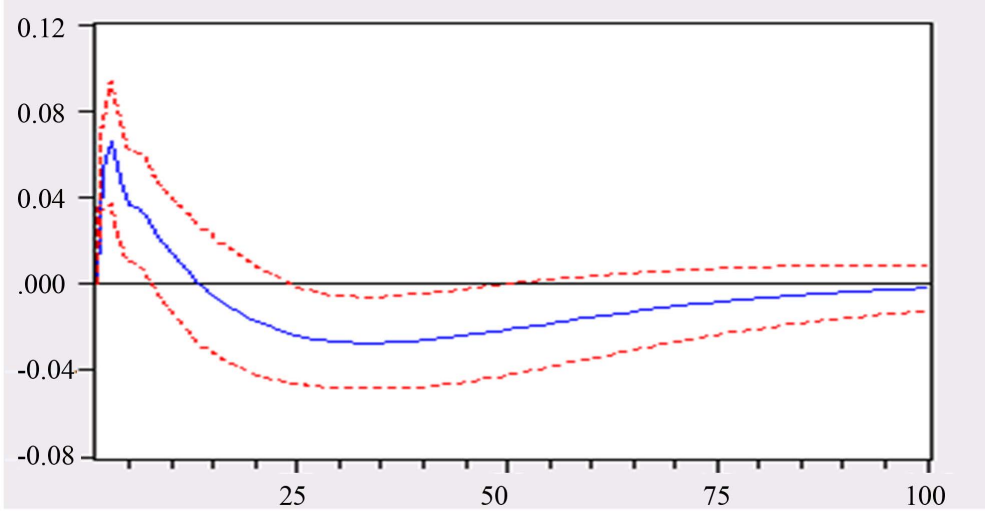

Figure 6. Impulse response of LNCN to LNCRB. Source: Eviews8.0.

price will rise. Judging from the confidence interval of the impulse response curve, all periods include 0 , indicating that the growth rate of industrial added value has a positive impact on the international commodity price, while this effect is insignificant.

As can be seen in Figure 6, in the short run, the response of the growth rate of industrial added value to a standard deviation shock from the international commodity price is positive during the first 13th periods and it reaches the maximum value 0.065 in the third period, and then the positive response gradually declines and turn to negative in 13th period. After reaching the maximum negative value in the 35th period, the negative response gradually weakens and disappears. This reflects that in the first 13th period, when the international commodity price rises, the growth rate of China's industrial added value will also accelerate. According to the confidence interval, this positive response is significant. After the 13th period, the response direction turns into a negative response, which reflects that after the 13th period, when the international commodity price rises, the growth rate of industrial added value will slow down. Combined with the confidence interval, we conclude that the negative response in the 25 th to 50 th period is significant.

\subsubsection{Variance Decomposition}

The main idea of variance decomposition is to decompose the fluctuation of each endogenous variable in the system into components related to the information of the equations according to their causes so as to understand the relative importance of each information to the endogenous variables of the model. As can be seen from the results of Figure 7 and Figure 8, the contribution of the shock from China's growth rate of industrial added value on fluctuations of the international commodity price gradually rises and starts to stabilize in 60th period and maintains at $8 \%$. In contrast, the contribution of the shock from the international commodity price on the fluctuation of the growth rate of industrial added value in China lags behind and fluctuates more widely, showing an overall upward trend. In 75 th period it stabilizes and maintains at 36\%. 


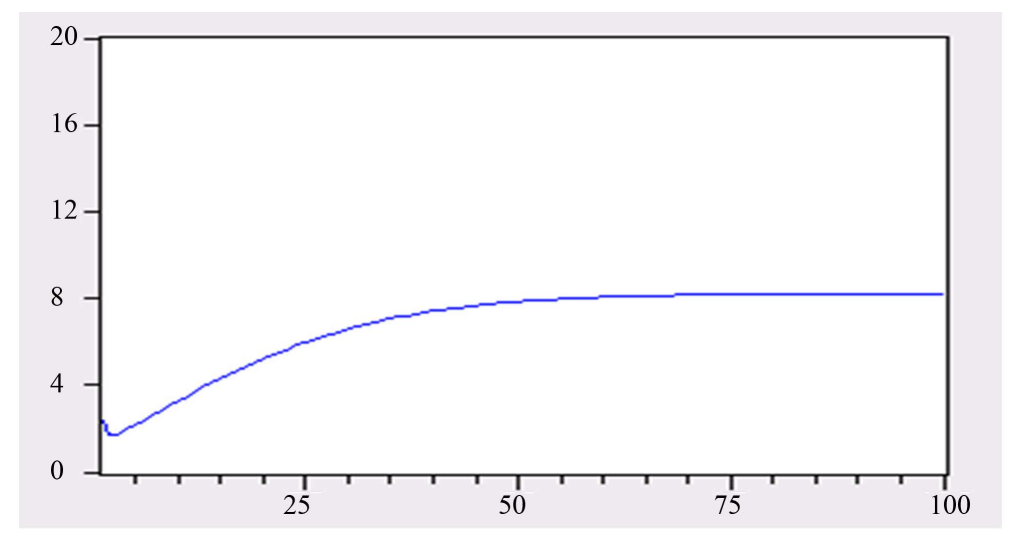

Figure 7. Contribution rate of the shock from LNCN.

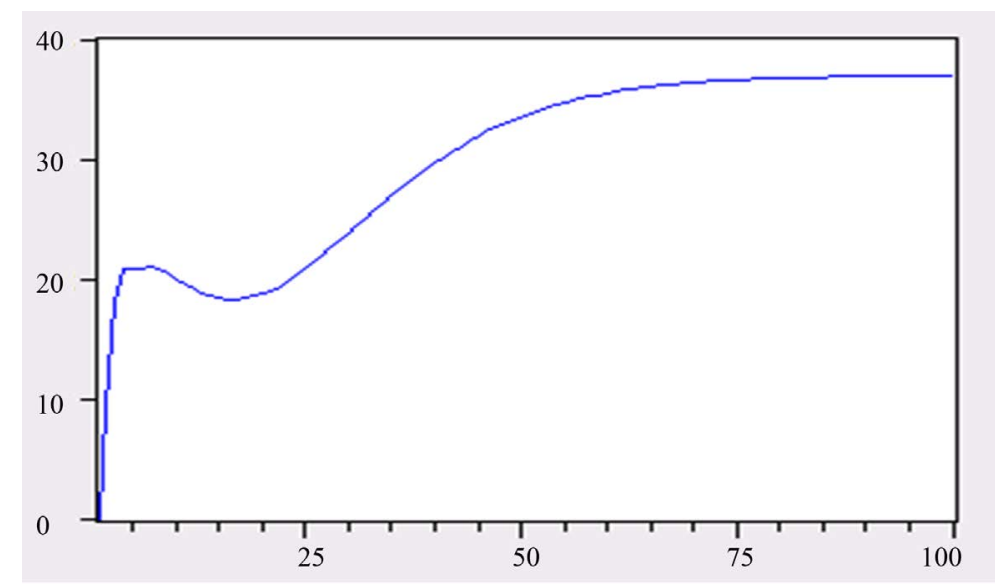

Figure 8. Contribution rate of the shock from LNCRB. Source: Eviews8.0.

\section{Conclusions and Implications}

Based on the relevant theoretical analysis and the monthly data from March 2002 to December 2015, this paper uses CRB index and the growth rate of industrial added value respectively as a measure of international commodity price and China's demand and constructs a VAR model to analyze interaction between the international commodity price and China's demand; the main conclusions are as follows:

First, the results of impulse response analysis show that the impact from the growth rate of industrial added value will lead to the positive response of commodity prices, indicating that the impact of industrial output growth can guide the fluctuation of international commodity price to a certain extent, which is in line with the theory of traditional commodity economic cycle. However, this effect is insignificant. In contrast, in the face of the impact of the fluctuation of international commodity price, the growth rate of industrial added value shows a significant positive response at the beginning, and then it shows a significant negative response, indicating that the impact of the shock from international commodity price on the growth rate of industrial added value will change over time: In the long run, the rising international commodity price will to some ex- 
tent hinder the growth rate of China's industrial output; while in the short term, as the international commodity price rise, the growth of China's industrial output will accelerate.

Second, the result of variance decomposition indicates that in the interaction between the growth rate of industrial added value and the international commodity price, the impact of the growth rate of industrial added value in China is increasingly significant on the fluctuation of international commodity price over time and ultimately it goes stable. On the contrary, the international commodity price over time have a stronger impact on the fluctuations of the growth rate of industrial added value, indicating that the impact from international commodity price can to a large extent lead to the swing of the growth rate of industrial added value.

The results of this study have the following implications:

First, the change in China's demand has a certain impact on the fluctuation of international commodity price, while the impact is not significant. From the aspect of supply and demand to analyze the reasons of the volatility of international commodity price is far from enough since the international commodities not only have the attributes of goods and the reasons for the price volatility is complex, and therefore we should focus on other factors that may affect the volatility of international commodity price, such as speculative investment factors, the monetary policy of the world's major economies and make full preparation for price changes caused by these factors.

Second, in the long run, fluctuations in international commodity price will hinder the China's demand, particularly in the context of the drastic dropping of international commodity price in the past two years and the slowdown of the international economic growth, the decrease of international commodity price will affect the production costs of manufacturers and improve our trading conditions, which will prompt China's demand to achieve a high degree of growth in the long run. In the meantime, we should take full advantage of the low commodity price nowadays and take muscular internationalization approach to buying important commodities cheaply for eventual global market improvement and selling on the macroeconomic trendlines based on national internal investment and restructuring strategies.

\section{References}

Anzuinie, A., Lombardi, M. J., \& Pagano, P. (2010). The Impact of Monetary Policy Shocks on Commodity Prices. ECB Working Paper No.1232, August 2010.

Arbatli, E. C., \& Vasishtha, G. (2012). Growth in Emerging Market Economies and the Commodity Boom of 2003-2008: Evidence from Growth Forecast Revisions. Bank of Canada, Working Paper No. 2012-8.

Baldi, L. Peri, M., \& Vandone, D. (2011). Price Discovery in Agricultural Commodities: The Shifting Relationship between Spot and Futures Prices. International Congress, Zurich, Switzerland, No. 114237.

Balke, N. S., Brown, S. P. A., \& Yucel, M. K. (2008). An International Perspective on Oil 
Price Shocks and US Economic Activity. Globalization and Monetary Policy Institute Working Paper, 20.

Belke, A., Bordon, I. G., \& Volz, U. (2013). Effects of Global Liquidity on Commodity and Food Prices. World Development, 44, 31-43.

https://doi.org/10.1016/j.worlddev.2012.12.009

Blanchard, O., \& Jordi, G. (2007). The Macroeconomics Effects of Oil Price Shocks: Why Are the 2000s So Different from the 1970s. Massachusetts Institute of Technology, Center for Energy and Environmental Policy Research, No. 18, 1-77.

Blattman, C., Hwang, J., \& Willamson, J. G. (2007). Winners and Losers in the Commodity Lottery: The Impact of Terms of Trade Growth and Volatility in the Periphery 1870-1939. Journal of Development Economics, 82, 156-179.

https://doi.org/10.1016/j.jdeveco.2005.09.003

Cavalcanti, T. V. V., Mohaddes, K., \& Raissi, M. (2012). Commodity Price Volatility and the Sources of Growth. IMF Working Paper WP/12/12.

Chang, Q. (2010). Macroeconomic Decision Making with Reference to Futures Price Index. Price Theory and Practice, No. 11, 13-14.

Cheung, C., \& Sylvie, M. (2007). The Impact of Emerging Asia on Commodity Prices. Bank of Canada, Working Paper.

Dwyer, A., Holloway, J., \& Wright, M. (2012). Commodity Market Financialisation: A Closer Look at the Evidence. RBA Bulletin, 3, 65-77.

Gilbert, C. L. (2010). Speculative Influences on Commodity Futures Prices 2006-2008. Working Paper, Trento: Department of Economics, University of Trento.

Hamilton, J. D. (2009). Causes and Consequences of the Oil Shock of 2007-08. NBER Working Paper No. W15002.

Han, K. (2006). Empirical Analysis of the Impact of International Oil Prices and Real Effective Exchange Rate of RMB on China's Economy. Beijing: University of International Business and Economics.

Han, L., \& Yin, L. (2012). Speculation or Actual Demand?-A Broad Perspective on the Influencing Factors of International Commodity Price. Economic Research, No. 12.

He, S., \& Chen, G. (2014). International Commodity Price and China's Demand. Financial Markets, 100-102.

Inamura, Y., Kimata, T., Kimura, T., \& Muto, T. (2011). Recent Surge in Global Commodity Prices - Impact of Financialization of Commodities and Globally Accommodative Monetary Condition. Bank of Japan Review.

Juvenal, L., \& Petrella, I. (2011). Speculation in the Oil Market. FRB of St. Louis Working Paper No. 2011-027E.

Kilian, L. (2009). Not All Oil Price Shocks Are Alike: Disentangling Demand and Supply Shocks in the Crude Oil Market. American Economic Review, 99, 1053-1069. https://doi.org/10.1257/aer.99.3.1053

Kilian, L., \& Murphy, D. (2011). The Role of Inventories and Speculative Trading in the Global Market for Crude Oil. Working Paper, Ann Arbor, MI: University of Michigan.

Lalonde, R., Philipp, M. et al. (2009). Emerging Asis's Impact on Food and Oil Prices: A Model-Based Analysis. Discussion Paper 09-3, Ottawa: Bank of Canada.

Landgraf, S., \& Chowdhury, A. (2011). Factoring Emerging Markets into the Relationship between Global Liquidity and Commodities. WPPI Energy Working Paper, No. 2011-07.

Li, C., Ma, W., \& Wang, B. (2009). Inflation Expectation and Macroeconomic Stabili- 
ty-An Analysis Based on Dynamic Stochastic General Equilibrium Model. Nankai Economic Research, No. 6, 30-53.

Li, L., \& Mu, Y. (2015). Research on the Influencing Factors of the Price Fluctuation on the International Commodity Market-Based on the Comparison of the Grouping Countries. International Finance, No. 10, 55-63.

Manera, M., Nicolini, M., \& Vignati, I. (2012). Returns in Commodities Futures Markets and Financial Speculation: A Multivariate GARCH Approach. Fondazione Eni Enrico Mattei Working Papers, Paper 674.

Roache, S., \& Rossi, M. (2010). The Effects of Economic News on Commodity Prices. Quarterly Review of Economics and Finance, 50, 377-385.

Sanders, D. R., \& Irwin, S. H. (2010). A Speculative Bubble in Commodity Futures Prices? Cross-Sectional Evidence. Agricultural Economics, 41, 25-32.

Singleton, K. (2011). Investor Flows and the 2008 Boom/Bust in Oil Prices. Working Paper, Stanford, CA: Stanford Graduate School of Business.

Tan, X., Liu, Y., \& Zhang, M. (2014). International Commodity Price Fluctuations: How Important China Factors Are-An Empirical Study Based on Quarterly Data from 1997 to 2012 and VECM Model. International Finance Research, No. 10, 75-86.

Thompson, A. S., \& Summers, P. M. (2012). The Effect of Monetary Policy on Real Commodity Prices: A Re-Examination. The Journal of Economics, 38, 1-21.

Wang, R. (2013). China's Factors and Financial Factors in Commodity Prices. Shanghai Finance, No. 5 . 